University of Nebraska - Lincoln

DigitalCommons@University of Nebraska - Lincoln

Faculty Publications in the Biological Sciences

Papers in the Biological Sciences

5-1901

An Addition to the Parasites of the Human Ear

Roscoe Pound

University of Nebraska - Lincoln

Follow this and additional works at: https://digitalcommons.unl.edu/bioscifacpub

Part of the Life Sciences Commons

Pound, Roscoe, "An Addition to the Parasites of the Human Ear" (1901). Faculty Publications in the Biological Sciences. 17.

https://digitalcommons.unl.edu/bioscifacpub/17

This Article is brought to you for free and open access by the Papers in the Biological Sciences at DigitalCommons@University of Nebraska - Lincoln. It has been accepted for inclusion in Faculty Publications in the Biological Sciences by an authorized administrator of DigitalCommons@University of Nebraska - Lincoln. 


\section{AN ADDITION TO THE PARASITES OF THE HUMAN EAR}

By ROSCOE POUND

WITH ONE PLATE

The list of Fungi which have been reported as parasites in the human ear is somewhat large. The number of species which are well identified is much smaller. The confusion long prevalent in the groups to which the ear-parasites belong, recently abated in the Black Moulds by $A$. Fischer, but still in force in the Imperfect Fungi, and the fact that otologists have not been much concerned with mycology nor always able to command the assistance of expert mycologists, have united with the inherent difficulties due to the effect of situs on the forms themselves to produce errors in determination, uncertainty, and even controversy. The greater number of the species reported and the greater number of the well identified and authenticated species belong to the Aspergillaceae. Next come the Mucoraceae. The Protoascineae and Pezizineae contribute one each. In addition there are several Imperfect Fungi, some of which, however, seem to owe their place upon the list to ubiquity rather than to any special adaptation to the habitat. It seems probable that almost any of the commoner pantogenous Imperfect Fungi is liable to be added to this portion of the list at any time.

The following species appear to constitute the fungus flora of the human ear:

Mucoraceae.

Mucor mucedo $\mathrm{L}$.

M. racemosus Fres.

M. corymbifer F. Cohn.

Ascophora mucedo Tode (Rhizopus nigricans Ehrb.).

Doubtful and less known species:

Thamnidium elegans Lk. (Ascophora elegans).

It has been suspected, with good reason, that the forms 
referred to $T$. elegans were merely Mucor mucedo with sporangiola.

Mucor septatus Bezold, according to A. Fischer, is probably to be referred to $M$. racemosus.

M. rhizoformis Lichth.

Endomycetaceae.

Bargellinia monospora Borzi.

This curious fungus, placed by Saccardo in the somewhat heterogeneous group of Gymnoascaceae, is doubtfully referred to the Endomycetaceae by Schroeter in the Pflanzenfamilien.

Aspergillaceae.

Aspergillus glaucus (L.) Lk. (A. herbariorum (L.) E. Fisch.).

A. repens (Corda) Sacc.

A. fumigatus (Fres.) De Bary.

A. malignus (Lindt.) E. Fisch. (Eurotium malignum Lindt.).

A. flavus $\mathrm{Lk}$.

A. virens $\mathrm{Lk}$.

A. nidulans (Eidam) Wint. (Sterigmatocystis nidulans).

A. niger Van Tiegh. (Sterigmatocystis nigra).

Penicillium crustaceum (L.) Fr.

$P$. minimum Siebenmann.

Doubtful or less known species:

Aspergillus flavescens Wred. Believed to belong to A. flavus.

A. hageni Hallier.

Otomyces hageni Hallier.

A. microsporus Boke.

A. nigrescens Robin.

A. nigricans Wred. (1868).

A. nigricans Cooke (1885).

Cooke says his $A$. nigricans appears to be distinct from $A$. nigrescens, but seems to consider it the same as $A$. nigricans of Wreden. Siebenmann refers $A$. nigrescens to A. fumigatus and A. nigricans Wred. to A. niger. Cooke's figure (Journ. Queckett Micr. Club, II, 2: t. 9 f. 3) precludes identification with $A$. niger. Cattaneo refers $A$. nigricans, to $A$. nigrescens, which would then mean, probably, A. fumigatus.

A. noelting Hallier.

A. ramosus Hallier. 
A. rubens Green. Believed to be A. nidulans.

Sterigmatocystis antacustica Cram. Supposed to be Aspergillus niger.

Otomyces purpureus Woronin is thought to belong to $A$. nidulans.

Mollisiaceae.

Mollisia auriculae (Garov.) Sacc.

Peziza auriculae Garov.

Fungi Imperfecti.

Alysidium rufescens (Fres.)

Torula rufescens Fres.

Oospora rufescens Sacc.

Verticillium graphii Bezold.

Acrostalagmus parasiticus Hallier.

Stachylidium sp. Hallier.

These seem likely to prove the same.

Trichothecium roseum Lk.

Stemphylium polymorphum Bon.

Graphium penicillioides Corda.

Coremium bicolor (Web.) Pound \& Clements.

Stysanus stemonites (Pers.) Corda.

Spores of one of the Ustilagineae (smuts) are also reported as found germinating in an infested ear, which is not to be wondered at in view of the ubiquity of these spores.

To the foregoing list we now have to add Sterigmatocystis candida.

The Mucoraceae enumerated include the three commonest of the Black Moulds. They are to be found on all manner of organic substances throughout the world, and their occurrence as ear-parasites is doubtless partially due to that fact. But some connection has been suggested between the growth of Mucor racemosus in the ear and cases of diabetes, which is rendered not improbable by the yeast-like mode of growth of this fungus and its power of acting as a ferment. $M$. corymbifer has been found to be pathogenic in other connections.

The nature and position of Bargellinia monospora are doubtful. It is placed provisionally in a small group of Ascomycetes or sac-fungi in which no spore-fruit is developed and the ascus is of a very primitive type. But it is not certain that Bargellinia is an Ascomycete at all. The so-called one- 
spored ascus may prove to be some form of conidial fructification.

Of the Aspergillaceae named, the ten listed as doubtful or less known are reported as ear-parasites only. But they require further study, and some at least are believed by competent authority to be identical with other species of more general occurrence. The type of this group, Aspergillus glaucus, is the ordinary herbarium mould found everywhere on all manner of organic substances. It occurs in the ear in the conidial stage in which the ends of certain fertile hyphae swell up and produce chains of asexual spores. The stage in which small, yellow, sexual spore-fruits are produced, visible to the naked eye, was long considered a distinct species, called Eurotium herbariorum, and by some the plant is now known as Aspergillus herbariorum. The rules of nomenclature adopted by American botanists, however, seem to justify the retention of the well known name $A$. glaucus. It has been suggested that the forms described under the name Otomyces represent this second stage of the Aspergilli also. This has been controverted by good authority, but the belief seems to be general that the Otomyces forms are connected with Aspergillus.

Under the name Aspergillus, besides the forms whose lifehistories are well worked out, which are known in both stages, mycologists include also a large number of forms known only in the first or asexual condition. Many of these may go on indefinitely in this stage and never develop further. Others possibly are but ill-understood variations of the better known forms. It is to this category of "Imperfect Fungi" that one or two of the more widely known species and all the species peculiar to the ear enumerated above are to be referred. The Aspergilli are among the commonest and most wide-spread of saprophytes, but in addition seem to find themselves at home in diseased animal tissues. Thus, in addition to the long list of Aspergilli which infest the human ear, A. fumigatus has been observed in the human lung, $A$. niger in the lungs of birds, $A$. malignus and $A$. nidulans are otherwise pathogenio, and $A$. virens has been found upon tissues imperfectly preserved in alcohol.

Penicillium crustaceum, the ordinary blue mould of cheese, fruit, jelly, etc., is the commonest of fungi. It is closely related to Aspergillus, producing a spore-fruit of the same sort, 
and is most readily distinguished in that the chains of conidia (asexual spores) proceed from verticillately branched hyphae instead of from a terminal swelling. This species also has a weakness for diseased tissues, having been found parasitic in other parts of the human body. P. minimum is known only as an ear-fungus.

The Aspergilli proper, which furnish the bulk of the species infesting the ear and, according to report, are the fungi usually met with in cases of otitis parasitica, fall into three groups. In the first, the chains of conidia proceed from mere roughenings of the terminal vesicle of the fertile hypha. In the second, they proceed from well developed but simple sterigmata. In the third group these sterigmata are branched. The first two are included in the genus Aspergillus, the third has been made a distinct genus under the name of Sterigmatocystis. But systematists who take into account the further development of S. nigra, the type, and its spore-fruit condition, now concur in uniting the genus with Aspergillus, so that it is kept separate chiefly because of the imperfect forms that are described under the other name. Sterigmatocystis nigra, or Aspergillus niger, is a very common saprophyte, only less common than A. glaucus and Penicillium crustaceum, and like them thoroughly pantogenous. S. antacustica, an ear-parasite described by Cramer in 1859, was referred to Aspergillus niger by Wilhelm in his monograph of Aspergillus, and afterwards by Winter and Siebenmann. E. Fischer in the Pflanzenfamilien places it there doubtfully. There is good reason to suspect that $A$. niger is more common in the ear than the reports would show, as at least one figure labeled A. nigricans has branching sterigmata and the general appearance of $A$. niger.

Mollisia auriculae, a cup-fungus discovered in Italy in $\mathbf{1 8 7 1}$ in a case of otitis, is known from a careful drawing made at the time by Dr. Frigerio. The name Peziza auriculae, under which it was published by Garovoglio in 1872, seems to have been a nomen nudum. The drawing shows a well developed spore fruit with asci and paraphyses as in typical Pezizineae.

The Imperfect Fungi reported give rise to many difficulties. Trichothecium roseum is one of the most common of saprophytes and is pantogenous. On the other hand, Stemphylium polymorphum, Graphium penicillioides, and Coremium bicolor are saprophytes of decaying wood and are by no means so 
common or widely distributed. Siebenmann believes the two first to be connected with the form described as Verticillium graphii, the forms referred to $G$. penicillioides being only compact growths of the conidiophores. It will not escape notice that Verticillium, Acrostalagmus, Stachylidium, Trichothecium, and Graphium, the genera of Imperfect Fungi under which ear-fungi are described, have the common characteristic of being conidial stages of Hypocreales. We may suspect, therefore, that some single nectrioid fungus may ultimately be found to account for most of these, though the pantogenous Trichothecium roseum scarcely needs to be accounted for. Coremium bicolor was not found in the ear but in cultures of mycelia taken from the ear, and its place on the list is doubtful. Alysidium rufescens was first noted as a growth on the lens in cataract.

Some time ago, Dr. S. E. Cook of Lincoln submitted to me material of an ear-parasite, plainly one of the Aspergillaceae, which had much of the outward appearance of the common A. candidus. Examination revealed branching sterigmata, and I referred the form provisionally to Sterigmatocystis candida Sacc. The latter species was discovered by Saccardo in Italy in $\mathbf{1 8 7 6}$ growing upon decaying insect larvae, and has since been found in France growing upon the surface of citric acid. It is probably pantogenous, like the rest of the group. While the form found by Dr. Cook differs from $S$. candida in being somewhat smaller at all points, the shape of the sterigmata is so characteristic, and agrees so thoroughly with Saccardo's figure (Fungi Italici, t. 80) that in the absence of authentic material for comparison, notwithstanding Professor Underwood's caution that American fungi identified by European names are a source of confusion and must be renamed, it seems best to refer this form to $S$. candida, noting the slight divergence in measurements.

A brief description, figures and bibliography are added. Sterigmatocystis candida Sacc.

In a human ear affected with otitis, Lincoln, Neb. (Dr. S. E. Cook).

Fertile hyphea hyaline or whitish, rather strict, 150 to $200 \times 10 \mu$; vesicle globose, 30 to $35 \mu$; basidia clavate, $30 \times 7 \frac{1}{2} \mu$, noticeably obtuse and flattened at the top, bearing three filiform sterigmata 10 to $15 \mu$ long; conidia gobose, not exceeding $2 \mu$. 


\section{PRINCIPAL WORKS CONSULTED}

Cattaneo, A. and Oliva, L.

Dei Miceti trovati sul corpo umano. 1883.

COOKE, M. C.

On Some Remarkable Moulds. Journ. Queckett Micr. Club, II; 2:138. 1885 .

SiebenmanN, F.

Schimmelmycosen des Ohres. 1889.

Neue botanische und klinische Beitraege zur Otomykose (1888), translated in Archives of Otology, 18:230, 1889.

WILHELM, K. A.

Beitraege zur Kenntniss der Pilzgattung Aspergillus. 1877.

SACCARDO, P. A.

Fungi Italici, t. 80. 1877.

Sylloge Fungorum, vol. 4, 1886; vol. 8, 1889.

FIsCHER, A.

Phycomycetes in Rabenhorst's Kryptogamenflora v. Deutschland, 2d Ed. 1892.

Engler, A. and Prante, K.

Die Natuerlichen Pflanzenfamilien, Th. I, Abt. 1, 119 et seq., 156, 297 et seq. 1893-1897.

BURNETT, C. H.

System of Diseases of the Ear, Nose, and Throat, vol. 1, pp. 190-203. 1893.

Roosa, D. B. ST. J.

Diseases of the Ear, 7th Ed. 1891. 


\section{Plate XVIII}

Sterigmatocystis candida Sacc.

(a.) Fertile hypha.

(b.) Terminal vesicle with "basidia" attached.

(c.) A single "basidium." 
Pate XVII

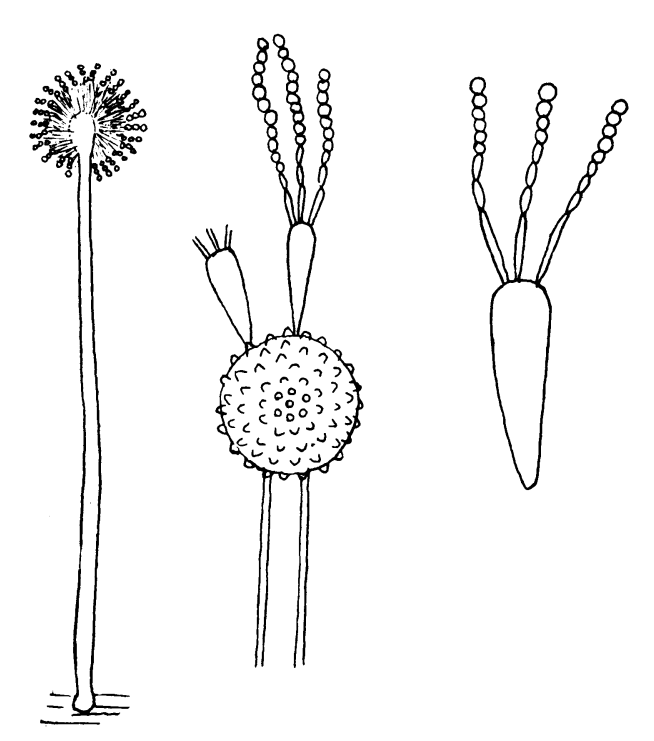

